\title{
Analisis Kebutuhan Penyediaan Air Bersih di Kota Palembang
}

\author{
Analysis of Water Demand Supply in Palembang City \\ M. Agung Kurniawan $1{ }^{1}{ }^{*}$, Heni Fitriani ${ }^{2}$, Febrian Hadinata ${ }^{3}$ \\ 1,2,3 Program Studi Magister Teknik Sipil, Universitas Sriwijaya, Jl. Sriwijaya Negara, Palembang, Indonesia
}

\begin{abstract}
* Penulis korespondensi : kurniawanm.agung@yahoo.co.id
Tel.: +62-81-278-700-747

Diterima: 02 September 2021, 2021; Direvisi: 31 Oktober 2021; Disetujui: 31 Oktober 2021
\end{abstract}

DOI: 10.25299/saintis2021.vol21(02).7611

\section{Abstrak}

Cakupan pelayanan air bersih di Kota Palembang pada tahun 2020 sebesar 83,22\%, sehingga masih ada 16,78\% penduduk Kota Palembang yang belum dapat terlayani. Kondisi tersebut akan semakin memburuk seiring bertambahnya kebutuhan air tiap tahunnya. Penelitian ini bertujuan untuk mengetahui cakupan pelayanan, kebutuhan air maksimum dan neraca air, sehingga diharapkan dapat menjawab persoalan yang akan dibahas. Penelitian dimulai dengan melakukan proyeksi penduduk dan proyeksi pelanggan. Hasil proyeksi akan menghasilkan proyeksi cakupan pelayanan. Perhitungan kebutuhan air didapatkan dari kebutuhan dari jumlan pelanggan yang telah diproyeksikan. Selanjutnya proyeksi kebutuhan air akan dihubungkan dengan rencana penambahan kapasitas produksi sehingga menghasilkan neraca air. Hasil penelitian menunjukkan bahwa pada tahun 2021 dan tahun selanjutnya diproyeksikan cakupan pelayanan akan mengalami perbaikan dan pada tahun 2030 pelayanan air bersih $100 \%$ Kota Palembang dapat tercapai. Kebutuhan air pada tahun 2021 sebesar 4.875 lps dan semakin meningkat pada tahun berikutnya hingga pada tahun 2033 kebutuhan air mencapai 7.146 lps. Kondisi neraca air juga diproyeksikan akan mengalami perbaikan, dimana pada tahun 2020 masih mengalami defisit kapasitas sebesar 257 lps dan pada tahun berikutnya hingga tahun 2031 dapat mempertahankan surplus kapasitas.

Kata Kunci: Cakupan pelayanan, kebutuhan air maksimum, neraca air

\begin{abstract}
The coverage of clean water services in Palembang City in 2020 is $83.22 \%$, so there are still 16.78\% of the population of Palembang City who have not been served. This condition will worsen as the demand for water increases every year. This study aims to determine service coverage, maximum water demand and water balance, so that it is expected to be able to answer the issues to be discussed. The research begins by conducting population projections and customer projections. The projection results will produce a projection of service coverage. The calculation of water needs is obtained from the needs of the projected number of customers. Furthermore, the projected water demand will be linked to the plan to increase production capacity so as to produce a water balance. The results of the study show that in 2021 and the following year it is projected that service coverage will improve and in $2030100 \%$ clean water services for Palembang City can be achieved. The need for water in 2021 is 4,875 lps and will increase in the following year until in 2033 the water needs will reach 7,146 lps. The condition of the water balance is also projected to improve, where in 2020 it will still experience a capacity deficit of 257 lps and in the following year until 2031 it can maintain a capacity surplus.
\end{abstract}

Keywords: Service coverage, maximum water demand, water balance

\section{PENDAHULUAN}

Ketersediaan air bersih diperkotaan merupakan salah satu hal penting yang harus dipenuhi. Air merupakan salah satu kebutuhan primer manusia dalam melakukan aktivitas seharihari. Banyak aktivitas yang bergantung dan memerlukan akan air bersih seperti mandi, minum, mencuci, memasak dan lain-lain. Pada penelitian ini Kota Palembang menjadi lokasi studi analisis kebutuhan air bersih. Kota Palembang menunjukkan trend peningkatan jumlah penduduk pada tiap tahunnya. Laju pertumbuhan penduduknya rata-rata sebesar 1,0146 \% [1]. Pertambahan penduduk dengan tingkat pertumbuhan yang tinggi akan mengakibatkan kebutuhan air bersih juga akan meningkat. Hal tersebut dikarenakan beberapa faktor yang mempengaruhi kebutuhan air bersih antara lain : jumlah penduduk, jumlah sambungan rumah dan jumlah jiwa setiap rumahnya [2].

PDAM Tirta Musi berperan penting dalam pemenuhan kebutuhan air bersih di Kota Palembang. Instalasi Pengolahan Air (IPA) nya memiliki kapasitas produksi sebesar 3.847 lps pada tahun 2019 [3]. Kapasitas tersebut belum dapat memenuhi kebutuhan air bersih di Kota Palembang. Permasalahan tersebut dapat terlihat dari banyaknya permohonan pemasangan sambungan baru (SR) yang belum dapat diproses. Penambahan pelanggan dari tahun 2015 sampai dengan tahun 2018 mengalami penurunan. Selain itu, cakupan pelayanan penyediaan air bersih pada tahun 2020 sebesar 83,22\%, sehingga masih ada 16,78\% penduduk Kota Palembang yang belum dapat dilayani [4]. 
Kondisi di atas jika tidak segera ditangani akan semakin memburuk. Hal tersebut dikarenakan kebutuhan air semakin meningkat seiring bertambahnya jumlah penduduk tiap tahunnya [2]. Angka cakupan pelayanan akan mengalami penurunan jika penambahan kebutuhan air bersih tidak diimbangi dengan penyediaannya. Dapat diartikan juga bahwa semakin banyak penduduk Kota Palembang yang tidak mendapatkan akses pelayanan air bersih. Salah satu penyelesaian permasalahan yang dapat dilakukan adalah dengan cara penambahan kapasitas produksi. Dalam perencanaan penambahan kapasitas produksi, dibutuhkan analisis kebutuhan air bersih sebagai acuan seberapa besar nilai kebutuhan air yang harus disediakan, sehingga penambahan kapasitas produksi dapat direncanakan dengan baik.

Penelitian sebelumnya berdasarkan studi literatur sudah banyak yang membahas tentang analisa kebutuhan air suatu wilayah perkotaan di Indonesia. Sebagai contoh Kajian Pengembangan Air Bersih PDAM Tirta Barito Kota Buntok [5], Analisis Kebutuhan Air Bersih di Kota Batam [6], Analisis Kebutuhan Air bersih PDAM Samboja Kutai Kartanegara [7], Proyeksi Kebutuhan Air Bersih di Kota Pulang Pisau [8] dan Penyediaan Air Minum Kota Surakarta [9]. Berdasarkan literatur di atas, analisis kebutuhan air bersih berdasarkan kebutuhan domestik dan non-domestik menggunakan standar peraturan Kementrian Pekerjaan Umum, dimana angka konsumsi air bersih didasarkan pada kategori kota berdasarkan jumlah penduduk. Kekurangan pada metode ini adalah dalam penentuan konsumsi air bersih diasumsikan secara umum dan tidak spesifik berdasarkan karakteristik penggunaan konsumsi air bersih perkotaan tertentu, padahal setiap kota memiliki karakteristik yang berbeda-beda. Nilai konsumsi air bersih pada analisis kebutuhan air bersih merupakan variabel yang penting, sehingga pendekatan dalam menentukan angka konsumsi yang dipilih harus lebih spesifik.

Berdasarkan penemuan di atas, pada penelitian ini analisis kebutuhan air bersihnya didasarkan pada angka konsumsi air bersih ril Kota Palembang yang didapatkan dari data historis konsumsi air bersih pelanggan PDAM Tirta Musi Palembang. Metode ini juga pernah dilakukan diluar negeri, tepatnya di negara turki dimana penentuan kebutuhan airnya didasarkan pada data historis konsumsi air ril [10]. Diharapkan dengan menggunakan metode ini akan memberikan hasil lebih akurat yang mencerminkan kondisi kebutuhan air yang lebih asli atau sesuai dengan lokasi studi kasus. Selain itu, pada penelitian ini juga dilengkapi proyeksi cakupan pelayanan dan neraca air sebagai parameter pelengkap dalam perhitungan analisis kebutuhan air bersih. Oleh karena itu, penelitian ini bertujuan untuk mengetahui cakupan pelayanan, kebutuhan air maksimum dan neraca air. Hasil dari penelitian ini dapat digunakan sebagai parameter perencanaan kebutuhan air bersih di Kota Palembang pada tahun mendatang. Penelitian ini juga diharapkan dapat dijadikan bahan pertimbangan bagi pembuatan keputusan PDAM Tirta Musi dalam menentukan rencana strategis perusahaan yang akan dicapai pada tahun mendatang.

\section{METODOLOGI PENELITIAN}

Penelitian ini memiliki beberapa tahapantahapan pengerjaan yang harus dilakukan. Tahapan tersebut dapat dilihat secara ringkas pada diagram alir penelitian di Gambar 1 di bawah ini.

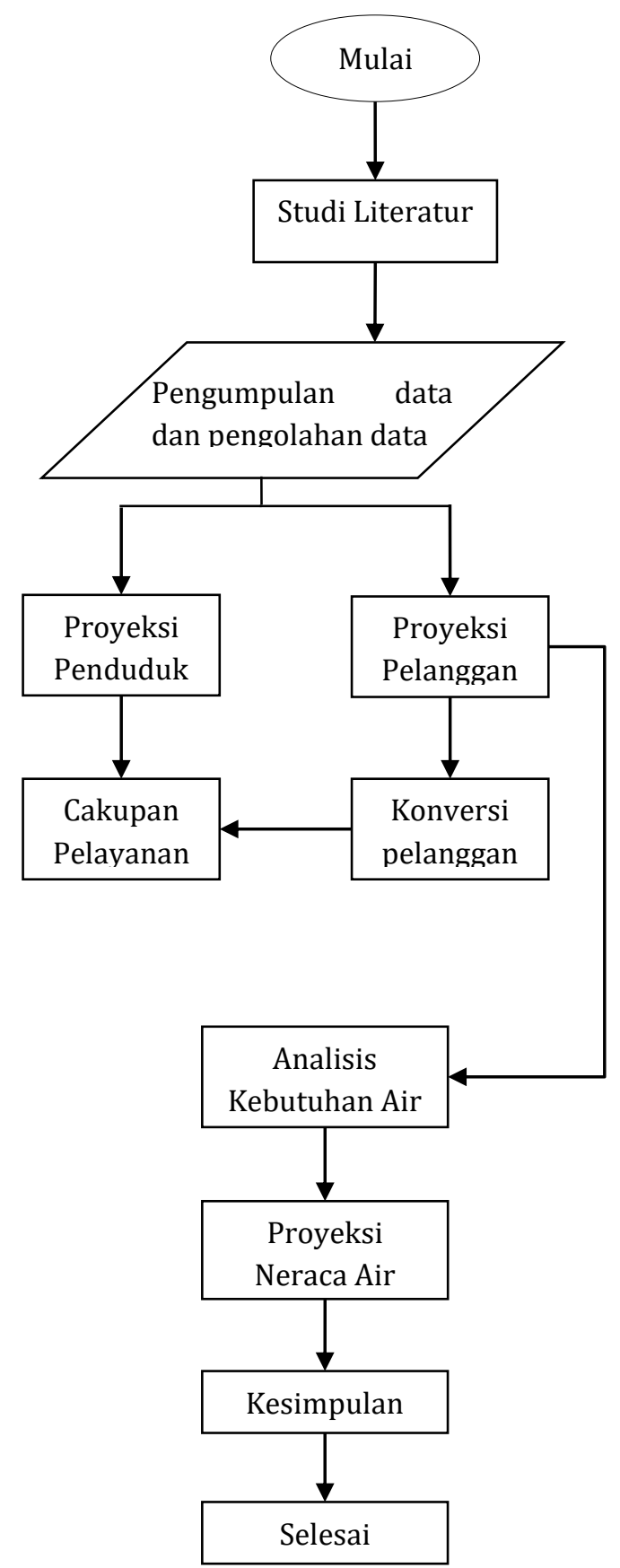

Gambar 1. Diagram alir penelitian

Proses studi literatur dilakukan pengumpulan beberapa referensi dari penelitian sebelumnya dan referensi peraturan-peraturan 
yang dibutuhkan dalam analisis penelitian ini. Kumpulan referensi ini akan dijadikan dasar dari perumusan masalah sampai tahap analisis. Proses selanjutnya ialah pengumpulan dan pengolahan data. Data yang dibutuhkan dalam penelitian ini berupa data penduduk, data pelanggan, data pemakaian air, data kehilangan air dan data rencana penambahan kapasitas produksi IPA. Data penduduk merupakan data jumlah penduduk Kota Palembang 10 tahun terakhir dari tahun 2010 sampai dengan 2019. Data pelanggan merupakan data pelanggan PDAM Tirta Musi 5 tahun terakhir dari tahun 2016 sampai dengan 2020. Data pemakaian air didapatkan dari pembukuan rekening air pelanggan dan data kehilangan air perpipaan PDAM Tirta Musi. Sedangkan data rencana penambahan kapasitas produksi merupakan Renbis PDAM Tirta Musi tahun 2019 sampai dengan 2023 yang menginduk pada RISPAM tahun 2014 sampai dengan 2033.

Proses selanjutnya adalah proyeksi penduduk dan proyeksi pelanggan. Proyeksi ini akan dilakukan sampai dengan tahun 2033 sesuai RISPAM PDAM Tirta Musi [11]. Selanjutnya dilakukan konversi pelanggan menjadi total jiwa penduduk terlayani. Dari hasil konversi ini akan didapatkan cakupan pelayanan yang akan dikorelasikan dengan proyeksi jumlah penduduk. Selanjutnya proses analisis kebutuhan air dimana proyeksi jumlah pelanggan akan dikalikan dengan konsumsi pemakaian ril pelanggan. Selanjutnya ditambah dengan faktor kehilangan air dan faktor harian maksimum. Dari hasil di atas, dilanjutkan dengan proses proyeksi neraca air. Proses ini akan menghubungkan antara kapasitas eksisting dan ditambah dengan penambahan kapasitas setiap tahun proyeksi dengan proyeksi kebutuhan, sehingga diketahui seberapa besar surplus atau defisit kapasitas. Setalah proses di atas dapat ditarik kesimpulan dari keseluruhan penelitian ini.

\section{HASIL DAN DISKUSI}

\section{Karakteristik Lokasi Penelitian}

Penelitian ini dilakukan pada wilayah pelayanan penyediaan air bersih Kota Palembang. Kota Palembang memiliki luasan wilayah administrasi sebesar 400,61 Km2 [1]. Kategori Kota Palembang berdasarkan jumlah penduduk merupakan Kota metropolitan. Hal ini dikarenakan jumlah penduduk kota Palembang memiliki lebih dari 1,6 juta jiwa. Berdasarkan standar dari peraturan Kementrian Perkerjaan Umum, Kategori kota metropolitan memiliki konsumsi air bersih lebih dari 190 liter/orang/hari. Konsumsi air bersih tiap perkotaan beragam. Untuk konsumsi air bersih di Kota Palembang berdasarkan data historis pelanggan PDAM Tirta Musi sebesar 226 liter/orang/hari dengan asumsi jumlah orang per sambungan/rumah sebesar 4,43 [12].

Secara geografis Kota Palembang dibelah oleh sungai besar yaitu sungai musi. Sungai ini merupakan sumber air baku utama yang digunakan PDAM Tirta Musi dalam penyediaan air bersih. Penyediaan air bersih di Kota Palembang sangat bergantung terhadap ketersediaan air bersih dari PDAM. Hal ini dikarenakan sumber lainnya seperti air sungai dan air tanah tidak layak untuk dapat dikonsumsi secara langsung [13]. Oleh karena itu, pada penelitian ini diasumsikan bahwa sumber air bersih penduduk Kota Palembang hanya berasal dari peyediaan air bersih PDAM Tirta Musi. Dapat diartikan bahwa cakupan pelayanan air bersih terhadap penduduk harus $100 \%$ untuk memastikan kebutuhan air bersih penduduk Kota Palembang dapat terpenuhi seluruhnya. Peta wilayah cakupan pelayanan PDAM Tirta Musi Palembang dapat dilihat pada gambar 2 di bawah ini.

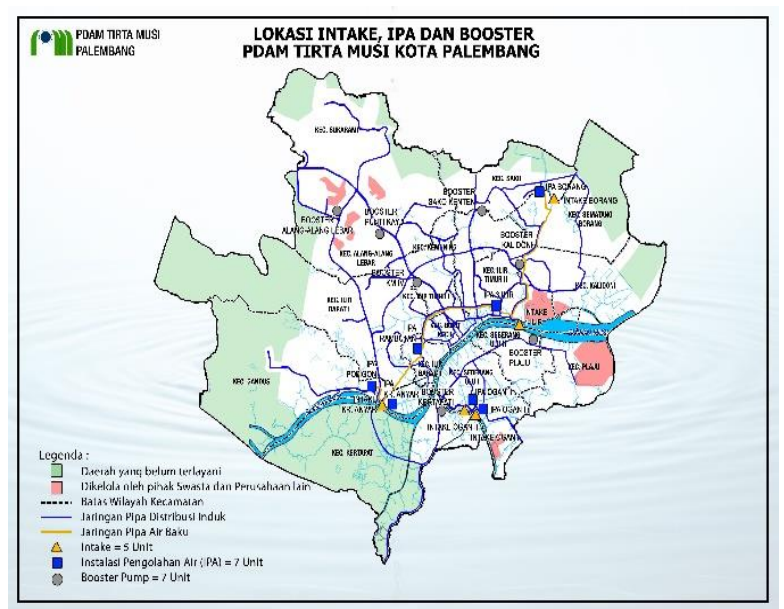

Gambar 2. Peta wilayah cakupan pelayanan PDAM Tirta Musi

\section{Proyeksi Jumlah Penduduk dan Pelanggan}

Perhitungan proyeksi jumlah penduduk dilakukan dengan menggunakan data 10 tahun terakhir jumlah penduduk Kota Palembang dari tahun 2010 sampai dengan 2019. Data pelanggan menggunakan data 5 tahun terakhir PDAM Tirta Musi. Kedua data tersebut akan di proyeksikan sampai tahun 2033. Jumlah penduduk dan Jumlah pelanggan dapat dilihat pada Gambar 3 dan 4 .

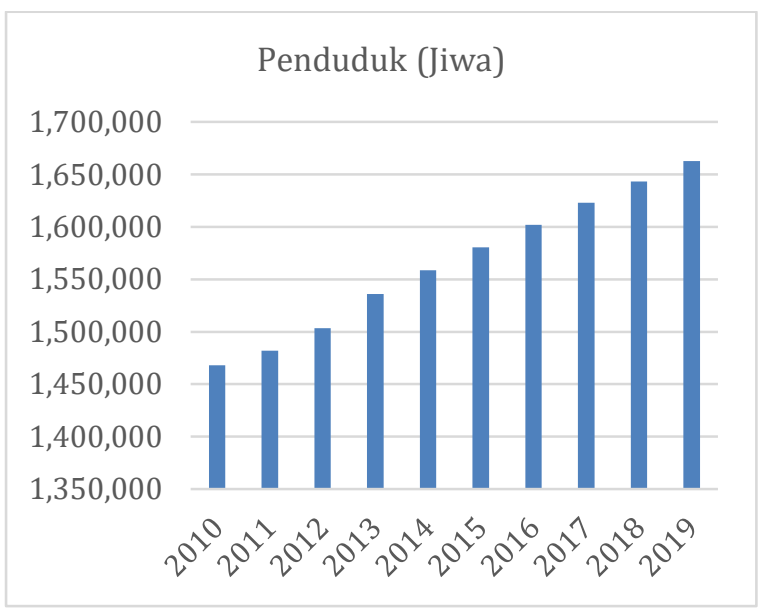

Gambar 3. Jumlah Penduduk Kota Palembang Sumber : BPS, 2019 


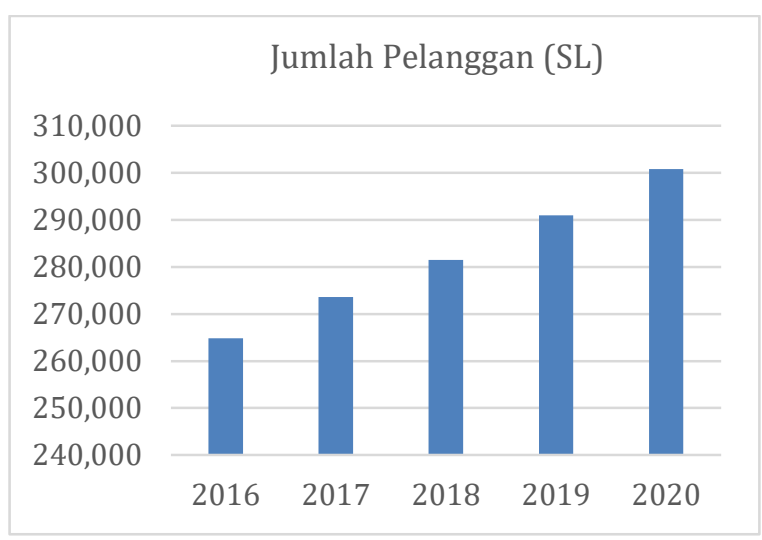

Gambar 4. Jumlah Pelanggan PDAM Tirta Musi Sumber : Tirta Musi, 2021

Berdasarkan pada penelitian sebelumnya di Kabupaten Aceh Utara dan Kawasan Sentul City, pada tahapan ini, jumlah penduduk dan jumlah pelanggan dapat diproyeksi menggunakan beberapa metode, antara lain : metode aritmatik, metode geometrik dan metode regresi linier [14][15]. Untuk menentukan metode yang dipilih dan paling cocok dengan data di atas, maka setiap data akan dilakukan uji korelasi. Nilai korelasi yang paling mendekati 1 akan dipilih dalam perhitungan proyeksi [5][16]. Dari hasil perhitungan, nilai korelasi ketiga metode dapat dilihat pada Tabel $1 \mathrm{di}$ bawah ini.

Tabel 1. Rekapitulasi nilai korelasi

\begin{tabular}{ll}
\hline Metode & Nilai Korelasi \\
\hline Aritmatik & 0,4117 \\
Geometrik & 0,9976 \\
Regresi Linier & 0.9966 \\
\hline \multicolumn{2}{l}{ Sumber : Hasil analisis data }
\end{tabular}

Berdasarkan hasil pengujian nilai korelasi, metode geometrik memiliki nilai korelasi yang paling mendekati 1 , sehingga metode geometrik yang akan digunakan dalam perhitungan proyeksi penduduk dan pelanggan. Metode geometrik digunakan jika data jumlah penduduk menunjukkan peningkatan yang pesat dari waktu kewaktu [17]. Secara matematis, metode ini dapat dituliskan dengan persamaan :

$$
\begin{aligned}
& \mathrm{Pn}=\mathrm{P} 0(1+\mathrm{r}) \mathrm{n} \\
& R=\frac{\sum_{i=1}^{n} \frac{P_{i}-P(i-1)}{P i}}{N}
\end{aligned}
$$

dimana :

Pn = Jumlah penduduk pada tahun yang diproyeksikan

Po = Jumlah penduduk awal

$r$ = Rata-rata angka pertumbuhan jumlah penduduk tiap tahun

$\mathrm{n}$ = Jangka waktu

$\mathrm{N}=$ Jumlah tahun

Perhitungan proyeksi dimulai dengan menghitung nilai rata-rata laju pertumbuhan menggunakan persamaan (2). Rekapitulasi perhitungan nilai $r$ untuk proyeksi penduduk dan pelanggan dapat dilihat pada Tabel 2 dan 3.

Tabel 2. Perhitungan nilai $\mathrm{r}$

\begin{tabular}{llll}
\hline Tahun & $\begin{array}{l}\text { Penduduk } \\
\text { (Jiwa) }\end{array}$ & $\begin{array}{l}\text { Laju } \\
\text { Pertumbuhan }\end{array}$ & $\begin{array}{c}\text { Rata- } \\
\text { rata Laju } \\
\text { Pertumb } \\
\text { uhan }\end{array}$ \\
\hline 2010 & 1468007 & 0 & \\
2011 & 1481814 & 0,0094052 & \\
2012 & 1503485 & 0,0146246 & \\
2013 & 1535900 & 0,0215599 & \\
2014 & 1558494 & 0,0147105 & 0,0139514 \\
2015 & 1580517 & 0,014130 & \\
2016 & 1602071 & 0,0136373 & \\
2017 & 1623099 & 0,0131255 & \\
2018 & 1643488 & 0,0125617 & \\
2019 & 1662893 & 0,0118072 & \\
\hline Sumber $:$ Hasilanalisis data
\end{tabular}

Tabel 3. Perhitungan nilai $r$

\begin{tabular}{llll}
\hline Tahun & $\begin{array}{l}\text { Pelanggan } \\
\text { (SL) }\end{array}$ & $\begin{array}{l}\text { Laju } \\
\text { Pertumbuhan }\end{array}$ & $\mathbf{r}$ \\
\hline 2016 & 264.839 & 0 & \\
2017 & 273.580 & 0,033004958 & \\
2018 & 281.462 & 0,028810586 & 0,0323 \\
2019 & 290.990 & 0,033851817 & \\
2020 & 300.838 & 0,033843087 & \\
\hline \multicolumn{5}{l}{ Sumber : Hasil analisis data }
\end{tabular}

Selanjutnya dilakukan perhitungan proyeksi sampai dengan tahun rencana menggunakan persamaan (1). Rekapitulasi perhitungan dapat dilihat pada Tabel 4 dan 5 .

Tabel 4. Proyeksi Jumlah Penduduk

\begin{tabular}{lll}
\hline Tahun & Tahun Ke- & Penduduk (Jiwa) \\
\hline 2020 & 1 & 1.686 .093 \\
2021 & 2 & 1.709 .616 \\
2022 & 3 & 1.733 .468 \\
2023 & 4 & 1.757 .652 \\
2024 & 5 & 1.782 .174 \\
2025 & 6 & 1.807 .038 \\
2026 & 7 & 1.832 .249 \\
2027 & 8 & 1.857 .811 \\
2028 & 9 & 1.883 .731 \\
2029 & 10 & 1.910 .011 \\
2030 & 11 & 1.936 .659 \\
2031 & 12 & 1.963 .678 \\
2032 & 13 & 1.991 .074 \\
2033 & 14 & 2.018 .853 \\
\hline
\end{tabular}

Sumber : Hasil analisis data 
Tabel 5. Proyeksi Jumlah Pelanggan

\begin{tabular}{llll}
\hline Tahun & $\begin{array}{l}\text { Tahun } \\
\text { Ke- }\end{array}$ & $\begin{array}{l}\text { Pelanggan } \\
\text { (SL) }\end{array}$ & $\begin{array}{l}\text { Penambahan } \\
\text { Pelanggan (SL) }\end{array}$ \\
\hline 2021 & 1 & 310.578 & 9.740 \\
2022 & 2 & 320.634 & 10.056 \\
2023 & 3 & 331.016 & 10.381 \\
2024 & 4 & 341.733 & 10.717 \\
2025 & 5 & 352.798 & 11.065 \\
2026 & 6 & 364.220 & 11.423 \\
2027 & 7 & 376.013 & 11.793 \\
2028 & 8 & 388.187 & 12.174 \\
2029 & 9 & 400.756 & 12.569 \\
2030 & 10 & 413.731 & 12.976 \\
2031 & 11 & 427.127 & 13.396 \\
2032 & 12 & 440.956 & 13.829 \\
2033 & 13 & 455.233 & 14.277 \\
\hline
\end{tabular}

Sumber : Hasil analisis data

\section{Proyeksi Cakupan Pelayanan}

Pada tahap ini, peneliti melakukan analisis untuk mengetahui seberapa besar cakupan pelayanan PDAM Tirta Musi dalam melayani kebutuhan air bersih di Kota Palembang. Tujuannya untuk dapat mengetahui pada tahun keberapa dalam proyeksi cakupan pelayanan mencapai $100 \%$, yang berarti semua kebutuhan air bersih penduduk Kota Palembang dapat terpenuhi secara keseluruhan.

Variabel yang dibutuhkan ialah jumlah penduduk keseluruhan dengan jumlah penduduk terlayani. Penduduk terlayani didapatkan dengan cara mengkonversikan jumlah pelanggan menjadi jumlah orang yang terlayani. Konversi ini didasarkan dari analisa pemakaian air bersih dari PDAM Tirta Musi dimana dalam satu jenis kategori pelanggan setara dengan sejumlah orang/penduduk yang dapat terlayani. Konversi tersebut dapat dilihat pada Tabel 6 di bawah ini :

Tabel 6. Konversi Pelanggan

\begin{tabular}{ll}
\hline Kategori Pelanggan & $\begin{array}{l}\text { Setara } \\
\text { (orang/penduduk) }\end{array}$ \\
\hline $\begin{array}{l}\text { Perumahan sangat sederhana, } \\
\text { rumah tangga perkampungan }\end{array}$ & 4,43 \\
lama9, rumah tangga menengah, \\
rumah tangga dan kos mewah, \\
Usaha kecil & 5,61 \\
Niaga kecil & 3,35 \\
Sosial umum & 9,99 \\
sosial khusus-a & 7,34 \\
sosial khusus-b & 11,26 \\
rs. Pemerintah tipe b & 1187,55 \\
kantor tni/polri/pemerintah & 27,53 \\
niaga besar-a & 18,44 \\
niaga besar-b & 221,79 \\
niaga khusus & 705,88 \\
\hline Sumber: $P D A M, 2019$ &
\end{tabular}

Selanjutnya dilakukan pengelompokan pelanggan sesuai kategorinya. Pelanggan dikelompokkan menjadi dua bagian besar, yaitu pelanggan domestik dan pelanggan non-domestik. Pelanggan domestik memiliki 6 (enam) sub kelompok pelanggan, antara lain : perumahan sangat sederhana, rumah tangga perkampungan lama, rumah tangga menengah, usaha kecil, rumah tangga dan kos mewah, niaga kecil. Pelanggan nondomestik memiliki 8 (delapan) sub kelompok pelanggan, antara lain : sosial umum, sosial khusus a, sosial khusus b, rumah sakit pemerintahan tipe b, kantor TNI/POLRI/Pemerintahan, niaga besar a, niaga besar $b$ dan niaga khusus. Setelah dilakukan pengelompokan sesuai kategori dan tiap tahun proyeksi, selanjutnya dilakukan konversi pelanggan menjadi penduduk terlayani dengan cara mengkalikan nilai konversi dengan setiap kategori pelanggan. Rekapitulasi penduduk terlayani dapat dilihat pada Tabel 7 di bawah ini.

Tabel 7. Proyeksi Penduduk Terlayani

\begin{tabular}{llll}
\hline \multirow{2}{*}{$\begin{array}{l}\text { Tahun } \\
\text { Proyeksi }\end{array}$} & \multicolumn{2}{l}{ Kategori Pelanggan } & \\
\cline { 2 - 3 } & Domestik & $\begin{array}{l}\text { Non- } \\
\text { domestik }\end{array}$ & Jumlah \\
\hline 2021 & 1.335 .150 & 113.110 & 1.448 .260 \\
2022 & 1.378 .381 & 116.543 & 1.494 .924 \\
2023 & 1.423 .015 & 121.216 & 1.544 .231 \\
2024 & 1.469 .091 & 124.847 & 1.593 .938 \\
2025 & 1.516 .650 & 140.332 & 1.656 .982 \\
2026 & 1.565 .758 & 144.646 & 1.710 .404 \\
2027 & 1.616 .450 & 149.061 & 1.765 .511 \\
2028 & 1.668 .790 & 154.341 & 1.823 .131 \\
2029 & 1.722 .821 & 160.201 & 1.883 .022 \\
2030 & 1.778 .596 & 165.037 & 1.943 .633 \\
2031 & 1.836 .186 & 170.238 & 2.006 .424 \\
2032 & 1.895 .636 & 175.324 & 2.070 .960 \\
2033 & 1.957 .012 & 181.803 & 2.138 .815 \\
\hline
\end{tabular}

Sumber : Hasil analisis data

Selanjutnya dilakukan perbandingan antara jumlah penduduk terlayani dengan jumlah penduduk total sehingga menghasilkan cakupan pelayanan dalam bentuk persentase. Rekapitulasi cakupan pelayanan dapat dilihat pada Tabel $8 \mathrm{di}$ bawah ini.

Tabel 8. Proyeksi Cakupan Pelayanan

\begin{tabular}{llll}
\hline $\begin{array}{l}\text { Tahun } \\
\text { Proyeksi }\end{array}$ & $\begin{array}{l}\text { Jumlah } \\
\text { Penduduk } \\
\text { Terlayani }\end{array}$ & $\begin{array}{l}\text { Jumlah } \\
\text { Penduduk } \\
\text { Palembang }\end{array}$ & $\begin{array}{l}\text { Cakupan } \\
\text { Pelayanan } \\
\text { (\%) }\end{array}$ \\
\hline 2021 & 1.448 .260 & 1.709 .616 & 84,71 \\
2022 & 1.494 .924 & 1.733 .468 & 86,24 \\
2023 & 1.544 .231 & 1.757 .652 & 87,86 \\
2024 & 1.593 .938 & 1.782 .174 & 89,44 \\
2025 & 1.656 .982 & 1.807 .038 & 91,70 \\
2026 & 1.710 .404 & 1.832 .249 & 93,35 \\
2027 & 1.765 .511 & 1.857 .811 & 95,03 \\
\hline
\end{tabular}




\begin{tabular}{llll}
\hline $\begin{array}{l}\text { Tahun } \\
\text { Proyeksi }\end{array}$ & $\begin{array}{l}\text { Jumlah } \\
\text { Penduduk } \\
\text { Terlayani }\end{array}$ & $\begin{array}{l}\text { Jumlah } \\
\text { Penduduk } \\
\text { Palembang }\end{array}$ & $\begin{array}{l}\text { Cakupan } \\
\text { Pelayanan } \\
\text { (\%) }\end{array}$ \\
\hline 2028 & 1.823 .131 & 1.883 .731 & 96,78 \\
2029 & 1.883 .022 & 1.910 .011 & 98,59 \\
2030 & 1.943 .633 & 1.936 .659 & 100,36 \\
2031 & 2.006 .424 & 1.963 .678 & 102,18 \\
2032 & 2.070 .960 & 1.991 .074 & 104,01 \\
2033 & 2.138 .815 & 2.018 .853 & 105,94 \\
\hline
\end{tabular}

Sumber : Hasil analisis data

\section{Proyeksi Kebutuhan Air Harian Maksimum}

Kebutuhan air terbagi menjadi dua, yaitu kebutuhan air domestik dan kebutuhan air nondomestik. Kebutuhan air domestik dihitung berdasarkan jumlah penduduk, tingkat pertumbuhan, kebutuhan air perkapita dan proyeksi waktu air akan digunakan [18]. Kebutuhan air non-domestik meliputi kebutuhan air yang digunakan di sekolahan, perkantoran, rumah ibadah, hidran, kegiatan komersial dan lain-lain. Pada penelitian ini, terdapat batasan-batasan dalam analisis kebutuhan air. Analisis tidak memuat kebutuhan air selain domestik dan non-domestik seperti kebutuhan air dalam proses industri besar, kebutuhan perkebunan, perikanan dan lain-lain. Selain itu, analisis kebutuhan air juga tidak memperhitungkan lonjakan kebutuhan air ketika adanya peningkatan turis domestik maupun luar negeri dan saat ada event atau kegiatan yang berlangsung di Kota Palembang seperti event Asean Games dan lain-lain.

Perhitungan kebutuhan air didasarkan dari estimasi penduduk masa depan dengan kebutuhan air tiap orang dalam satu harinya [19]. Dalam penelitian ini, kebutuhan air rata-rata dihitung berdasarkan jumlah pelanggan dengan konsumsi ril per pelanggan tiap harinya. kebutuhan orang per harinya menggunakan konsumsi ril per pelanggan PDAM Tirta Musi yaitu sebesar $1 \mathrm{~m}^{3} /$ hari [12]. Pada penelitian sebelumnya, seperti di Kab. Bolaang Mongondow Timur, Kab. Minahasa Tenggara, Kota Tarakan, Kota Langsa dan Kab. Pulang Pisau, total kebutuhan air rata-rata didapatkan dari penjumlahan kebutuhan domestik, kebutuhan nondomestik dan kehilangan air [20][21][22][23][24]. Kehilangan air didapatkan dari air yang terdistribusi dikurangi dengan air yang terjual. Kehilangan air ril pada PDAM Tirta Musi sebesar $20 \%$. Berdasarkan penelitian yang sudah dilakukan di Kota Buntok [5], Kab. Blitar [16], Kota Batam [6], Kota Tarakan [22], kehilangan air diambil nilai 20\% sesuai standar yang telah ditetapkan oleh Kementrian PU untuk wilayah perkotaan. Akan tetapi, penggunaan nilai kehilangan menggunakan data ril akan menghasilkan analisis yang lebih sesuai dengan kondisi lokasi penelitian seperti halnya yang pernah dilakukan penelitian di Turki [10]. Berdasarkan referensi di atas, pada penelitian ini nilai kehilangan air diambil angka 20\% sesuai dengan data ril dan standar Kementrian PU. Proyeksi kebutuhan air rata-rata dapat dilihat pada Tabel 9 di bawah ini.

Tabel 9. Proyeksi Kebutuhan Air Rata-rata

\begin{tabular}{lll}
\hline $\begin{array}{l}\text { Tahun } \\
\text { Proyeksi }\end{array}$ & $\begin{array}{l}\text { Jumlah } \\
\text { Sambungan } \\
\text { (SL) }\end{array}$ & $\begin{array}{l}\text { Kebutuhan Air } \\
\text { Rata-rata (lps) }\end{array}$ \\
\hline 2021 & 310.578 & 4.432 \\
2022 & 320.634 & 4.575 \\
2023 & 331.016 & 4.723 \\
2024 & 341.733 & 4.876 \\
2025 & 352.798 & 5.034 \\
2026 & 364.220 & 5.197 \\
2027 & 376.013 & 5.365 \\
2028 & 388.187 & 5.539 \\
2029 & 400.756 & 5.719 \\
2030 & 413.731 & 5.904 \\
2031 & 427.127 & 6.095 \\
2032 & 440.956 & 6.292 \\
2033 & 455.233 & 6.496 \\
\hline
\end{tabular}

Sumber : Hasil analisis data

Pada penelitian ini, perhitungan kebutuhan air digunakan sebagai dasar penentuan kapasitas IPA yang harus diproduksi PDAM Tirta Musi dalam menyediakan air bersih di Kota Palembang. Oleh karena itu, kapasitas produksi didasarkan pada perhitungan kebutuhan air harian maksimum. Kebutuhan air maksimum digunakan untuk mengakomodir kebutuhan air harian yang lebih besar dari biasanya. Faktor harian maksimum berkisar 1,05 sampai dengan 1,15 [6]. Pada penelitian ini menggunakan nilai faktor harian maksimum sebesar 1,1 atau $110 \%$ seperti halnya yang dilakukan pada penelitian sebelumnya [20][21][24]. Kebutuhan harian maksimum dapat dilihat pada Tabel 10 di bwah ini.

Tabel 10. Proyeksi Kebutuhan Air Maksimum

\begin{tabular}{|c|c|c|}
\hline $\begin{array}{l}\text { Tahun } \\
\text { Proyeksi }\end{array}$ & $\begin{array}{l}\text { Jumlah } \\
\text { Sambungan } \\
\text { (SL) }\end{array}$ & $\begin{array}{l}\text { Kebutuhan Air } \\
\text { Maksimum (lps) }\end{array}$ \\
\hline 2021 & 310.578 & 4.875 \\
\hline 2022 & 320.634 & 5.033 \\
\hline 2023 & 331.016 & 5.196 \\
\hline 2024 & 341.733 & 5.364 \\
\hline 2025 & 352.798 & 5.538 \\
\hline 2026 & 364.220 & 5.717 \\
\hline 2027 & 376.013 & 5.902 \\
\hline 2028 & 388.187 & 6.093 \\
\hline 2029 & 400.756 & 6.290 \\
\hline 2030 & 413.731 & 6.494 \\
\hline 2031 & 427.127 & 6.704 \\
\hline 2032 & 440.956 & 6.921 \\
\hline 2033 & 455.233 & 7.146 \\
\hline
\end{tabular}

Sumber : Hasil analisis data 


\section{Proyeksi Neraca Air}

Proyeksi neraca air dibutuhkan dalam mengetahui kondisi selisih kapasitas produksi air bersih yang tersedia terhadap kebutuhan air bersih pelanggan pada tahun mendatang. Proyeksi ini dibutuhkan sebagai indikator PDAM dalam melakukan perencanaan investasi pada tahun mendatang terkait kegiatan dalam menyeimbangkan antara ketersediaan dengan permintaan air bersih.

Perhitungan proyeksi neraca air membutuhkan proyeksi kebutuhan air maksimum yang sudah dihitung sebelumnya, kapasitas produksi eksisting dan rencana penambahan kapasitas produksi sesuai dengan Renbis PDAM Tirta Musi tahun 2019-2023. Diasumsikan pelaksanaan atau masa konstruksi setiap penambahan atau optimalisasi kapasitas produksi selama 1 tahun, sehingga penambahan kapasitas dalam perhitungan akan dimasukkan pada tahun berikutnya setelah masa konstruksi. Rekapitulasi rencana proyeksi penambahan kapasitas produksi dan eksisting kapasitas produksi dapat dilihat pada Tabel 11 di bawah ini.

Tabel 11. Proyeksi kapasitas produksi

\begin{tabular}{|c|c|c|c|c|c|}
\hline \multirow{2}{*}{ Nama IPA } & \multicolumn{5}{|c|}{ Penambahan Kapasitas (Lps) } \\
\hline & 2020 & 2021 & 2022 & 2023 & 2025 \\
\hline $\begin{array}{l}\text { IPA } 3 \text { Ilir } \\
\text { IPA }\end{array}$ & 210 & & & & \\
\hline Rambutan & 95 & & & & \\
\hline IPA Poligon & & 20 & & & \\
\hline IPA Ogan & & & & & 200 \\
\hline $\begin{array}{l}\text { IPA Borang } \\
\text { IPA Karang } \\
\text { Anyar } 2\end{array}$ & 40 & $\begin{array}{r}70 \\
500\end{array}$ & & & \\
\hline IPA Poligon 2 & & 150 & & & \\
\hline IPA Gandus & & & & 700 & \\
\hline IPA Kalidoni & & & 200 & & \\
\hline IPA Ogan 2 & 120 & 380 & & & \\
\hline $\begin{array}{l}\text { Jumlah } \\
\text { Penambahan }\end{array}$ & 465 & 1120 & 200 & 700 & 200 \\
\hline $\begin{array}{l}\text { Kapasitas } \\
\text { Eksisting }\end{array}$ & 4030 & 4029 & 4029 & 4029 & 4029 \\
\hline $\begin{array}{l}\text { Total } \\
\text { Kapasitas } \\
\text { Produksi }\end{array}$ & 4495 & 5615 & 5815 & 6515 & 6715 \\
\hline
\end{tabular}

Perhitungan neraca air dihasilkan dari pengurangan nilai kebutuhan air maksimum (lps) dengan nilai proyeksi kapasitas produksi (lps). Nilai selisih kapasitas (lps) dengan angka negatif menunjukkan bahwa penyediaan air bersih dari PDAM Tirta Musi belum dapat memenuhi kebutuhan air bersih penduduk Kota Palembang. Sedangkan jika nilainya positif menunjukkan bahwa penyediaan air sudah dapat memenuhi kebutuhan air bersih penduduk Kota Palembang. Rekapitulasi proyeksi neraca air dapat dilihat pada Tabel $12 \mathrm{di}$ bawah ini.

Tabel 12. Proyeksi Neraca Air

\begin{tabular}{|c|c|c|c|}
\hline $\begin{array}{l}\text { Tahun } \\
\text { Proyeksi }\end{array}$ & $\begin{array}{l}\text { Kapasitas } \\
\text { Produksi } \\
\text { (Lps) }\end{array}$ & $\begin{array}{l}\text { Kebutuhan } \\
\text { Air } \\
\text { Maksimum } \\
\text { (lps) }\end{array}$ & $\begin{array}{l}\text { Selisih } \\
\text { Kapasitas } \\
\text { (Lps) }\end{array}$ \\
\hline 2020 & 4.495 & 4.752 & -257 \\
\hline 2021 & 5.615 & 4.875 & 740 \\
\hline 2022 & 5.815 & 5.033 & 782 \\
\hline 2023 & 6.515 & 5.196 & 1.319 \\
\hline 2024 & 6.515 & 5.364 & 1.151 \\
\hline 2025 & 6.715 & 5.538 & 1.177 \\
\hline 2026 & 6.715 & 5.717 & 998 \\
\hline 2027 & 6.715 & 5.902 & 813 \\
\hline 2028 & 6.715 & 6.093 & 622 \\
\hline 2029 & 6.715 & 6.290 & 424 \\
\hline 2030 & 6.715 & 6.494 & 221 \\
\hline 2031 & 6.715 & 6.704 & 10 \\
\hline 2032 & 6.715 & 6.921 & -207 \\
\hline 2033 & 6.715 & 7.146 & -431 \\
\hline
\end{tabular}

Sumber : Hasil analisis data

\section{KESIMPULAN}

Dari hasil penelitian ini menunjukkan bahwa cakupan pelayanan air bersih Kota Palembang mengalami peningkatan tiap tahunnya dan akan mencapai cakupan pelayanan $100 \%$ pada tahun 2030. Kebutuhan air maksimum pada tahun proyeksi 2021 sebesar 4.875 lps dan semakin meningkat pada tiap tahunnya, sehingga pada tahun proyeksi 2033 kebutuhan air maksimum mencapai 7.146 lps. Sedangkan untuk neraca air, tahun pertama proyeksi pada tahun 2021 masih mengalami defisit kapasitas. Hal ini berarti pada tahun 2021 penyediaan air bersih belum dapat memenuhi kebutuhan air bersih Kota Palembang. Akan tetapi, pada tahun-tahun berikutnya neraca air mengalami perbaikan dan menghasilkan surplus kapasitas yang artinya penyediaan air bersih melebihi kebutuhan air bersih Kota Palembang. Kondisi surplus kapasitas ini dapat bertahan hingga tahun 2031.

\section{REFERENSI}

[1] “Laporan data," Palembang, 2019. [Online]. Available: https://palembangkota.bps.go.id/.

[2] M. M. Haque, P. Egodawatta, A. Rahman, and A. Goonetilleke, "Assessing the significance of climate and community factors on urban water demand," Int. J. Sustain. Built Environ., vol. 4, no. 2, pp. 222-230, 2015, doi: 10.1016/j.ijsbe.2015.11.001.

[3] "Laporan Realisasi \& Evaluasi Produksi," Palembang, 2019.

[4] "Rencana Bisnis PDAM Tirta Musi Tahun 
2019-2023," Palembang, 2019.

[5] E. Wahyu Diana, M. Sholichin, and R. Haribowo, "Kajian Pengembangan Jaringan Distribusi Air Bersih pada PDAM Tirta Barito Kota Buntok," J. Tek. Pengair., vol. 11, no. 1, pp. 8-17, May 2020, doi: 10.21776/ub.pengairan.2020.011.01.02.

[6] A. Wahyuni and Junianto, "Analisa Kebutuhan Air Bersih Kota Batam Pada Tahun 2025," Tapak, vol. 6, no. 2, pp. 116126, 2017.

[7] A. N. S. I. Hendriyani, M. Kencanawati, "Analisis Kebutuhan Air Bersih IPA PDAM Samboja Kutai Kartanegara," Media Ilm. Tek. Sipil, vol. 7, no. 1, pp. 87-97, 2019.

[8] M. V. Burako, "Proyeksi Kebutuhan Air Bersih Pada Tahun 2021 di Kota Pulang Pisau Menggunakan Metode Aritmatik," Media Ilm. Tek. Sipil, vol. 6, pp. 79-84, 2018.

[9] S. G.L. Yudha, S. Qomariyah, "Studi Kelayakan Penyediaan Air Minum Kota Surakarta Planning Horizon 10 Tahun (Studi Kasus PDAM Kota SURAKARTA)," Matriks Tek. Sipil, pp. 860-865, 2014, [Online]. Available:

https://digilib.uns.ac.id/dokumen/detail/4 2266/Analisis-Biaya-Manfaat-Bcr-

Pembuatan-Reservoir-Penyediaan-Air-diPDAM-Surakarta-Planning-Horizon-10-

Tahun-Studi-Kasus-PDAM-Kota-

SURAKARTA.

[10] C. Koç, R. Bakış, and Y. Bayazıt, "A study on assessing the domestic water resources, demands and its quality in holiday region of Bodrum Peninsula, Turkey," Tour. Manag., vol. 62, pp. 10-19, 2017, doi: 10.1016/j.tourman.2017.03.024.

[11] "Penyusunan Rencana Induk Sistem Penyediaan Air Minum," Jakarta, 2014.

[12] "Laporan Data Pelanggan," Palembang, 2020.

[13] Y. Windusari and N. P. Sari, "Kualitas Perairan Sungai Musi di Kota Palembang Sumatera Selatan," Bioeksperimen J. Penelit. Biol., vol. 1, no. 1, pp. 1-5, 2015, [Online]. Available:

https://journals.ums.ac.id/index.php/bioek sperimen/article/view/309/266.

[14] S. Susilah, "Studi Analisa Kapasitas Debit Terhadap Kebutuhan Air Bersih Proyeksi Tahun 2009 - 2014 Pada Ipa Bantuan Oxfam (Pdam Tirta Mon Pase) Kabupaten Aceh Utara," Teras J., vol. 3, no. 2, p. 105, 2017, doi: $10.29103 /$ tj.v3i2.36.

[15] A. Suheri, C. Kusmana, M. Y. J. Purwanto, and Y. Setiawan, "Model Prediksi Kebutuhan Air Bersih Berdasarkan Jumlah Penduduk di Kawasan Perkotaan Sentul City," J. Tek. Sipil dan Lingkung., vol. 4, no. 3, pp. 207-218, 2019, doi: 10.29244/jsil.4.3.207-218.

[16] E. Rohmaningsih, M. Sholichin, and R. Haribowo, "Kajian Pengembangan Sistem
Penyediaan Air Bersih Pada Daerah Rawan Air Di Desa Sumbersih Kecamatan Panggungrejo Kabupaten Blitar," J. Tenik Pengair., vol. 008, no. 01, pp. 48-59, 2017, doi: 10.21776/ub.jtp.2017.008.01.05.

[17] 0. B. S. S.M. Adioetomo, Dasar-dasar Demografi, 2nd ed. Jakarta: Penerbit Salemba Empat, 2010.

[18] B. Yulistiyanto and B. A. Kironoto, "Kajian Pengembangan Pengelolaan Sumberdaya Air Padawilayah Sungai Progo-Opak Serang Dengan Ribasim," Din. Tek. SIPIL, vol. 8, no. 1, pp. 10-20, 2008.

[19] B. R. Pickard, M. Nash, J. Baynes, and M. Mehaffey, "Planning for community resilience to future United States domestic water demand," Landsc. Urban Plan., vol. 158, pp. 75-86, 2017, doi: 10.1016/j.landurbplan.2016.07.014.

[20] I. Agustin, N. Sari, A. Karim, C. J. Supit, and L. A. Hendratta, "Perencanaan Sistem Penyediaan Air di Desa Motongkad Utara Kecamatan Nuangan Kabupaten Bolaang Mongondow Timur," J. Sipil Statik, vol. 4, no. 11, pp. 705-714, 2016.

[21] E. M. W. Anastasya Feby Makawimbang Lambertus Tanudjaja, "Perencanaan Sistem Penyediaan Air Bersih," J. sipil statik, vol. 5, no. 1, pp. 985-994, 2017.

[22] Asta, "Analisis Kebutuhan Air Bersih Dan Distribusi Jaringan PDAM Persemaian Kota Tarakan," Anal. Kebutuhan Air Bersih Dan Distrib. Jar. PDAM Persemaian Kota Tarakan, vol. 2, no. 1, pp. 61-68, 2018.

[23] F. A. Gani, "Efek Penambahan Debit Kebutuhan Pada Daerah Layanan Terhadap Kondisi Existing Pipa Air Bersih Kota Langsa," Teras J., vol. 8, no. 1, p. 350, 2018, doi: $10.29103 /$ tj.v8i1.143.

[24] U. Fitriati, S. A. Fathurrachman, and A. Rusdiansyah, "Studi Kebutuhan Air Bersih Di Kabupaten Pulang Pisau," Jukung (Jurnal Tek. Lingkungan), vol. 4, no. 2, pp. 34-41, 2018, doi: $10.20527 /$ jukung.v4i2.6582.

\section{NOMENKLATUR}

PDAM Perusahaan Daerah Air Minum

Renbis Rencana Bisnis

RISPAM Rencana Induk Sistem Penyediaan Air Minum

Lps Liter Per Second

r Nilai Korelasi 